\title{
SOCIO-DEMOGRAPHIC AND EPIDEMIOLOGICAL CHARACTERISTICS ASSOCIATED WITH HUMAN IMMUNODEFICIENCY VIRUS TYPE I (HIV-1) INFECTION IN HIV-1-EXPOSED BUT UNINFECTED INDIVIDUALS, AND IN HIV-1-INFECTED PATIENTS FROM A SOUTHERN BRAZILIAN POPULATION
}

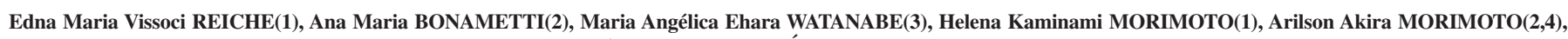
Susana Lilian WIECHMANN(2), José Wander BREGANÓ(1), Tiemi MATSUO(5) \& Fernando Vissoci REICHE(6)

\begin{abstract}
SUMMARY
The ability to control human immunodeficiency virus type 1 (HIV-1) infection and progression of the disease is regulated by host and viral factors. This cross-sectional study describes the socio-demographic and epidemiological characteristics associated with HIV-1 infection in 1,061 subjects attended in Londrina and region, south of Brazil: 136 healthy individuals (Group 1), 147 HIV-1-exposed but uninfected individuals (Group 2), 161 HIV-1-infected asymptomatic patients (Group 3), and 617 patients with AIDS (Group 4). Data were obtained by a standardized questionnaire and serological tests. The age of the individuals ranged from 15.1 to 79.5 years, $54.0 \%$ and $56.1 \%$ of the Groups 3 and 4 patients, respectively, were men. The major features of groups 2,3 , and 4 were a predominance of education level up to secondary school $(55.8 \%, 60.2 \%$ and $62.4 \%$, respectively), sexual route of exposure $(88.4 \%, 87.0 \%$ and $82.0 \%$, respectively), heterosexual behavior $(91.8 \%, 75.2 \%$ and $83.7 \%$, respectively), and previous sexually transmitted diseases $(20.4 \%, 32.5 \%$, and $38.1 \%$, respectively). The patients with AIDS showed the highest rates of seropositivity for syphilis $(25.6 \%)$, of anti-HCV $(22.3 \%)$, and anti-HTLV I/II obtained by two serological screening tests (6.2\% and $6.8 \%$, respectively). The results documenting the predominant characteristics for HIV-1 infection among residents of Londrina and region, could be useful for the improvement of current HIV-1 prevention, monitoring and therapeutic programs targeted at this population.
\end{abstract}

KEYWORDS: AIDS; Human immunodeficiency virus type 1 (HIV-1); Vulnerability; Risk factors; Epidemiology.

\section{INTRODUCTION}

The natural history and pathogenic processes of human immunodeficiency virus type 1 (HIV-1) infection are complex and variable, and depend on a multitude of viral and host factors and their interactions ${ }^{36}$. HIV-1-infected individuals present different rates of disease progression ${ }^{24,32,42}$. In addition, the susceptibility to HIV-1 infection seems to vary widely among individuals and several groups that are at risk for HIV-1 infection but have not become infected, defined as exposed but uninfected, have been reported ${ }^{5,17,27,39}$. The ability to control the infection and to delay the progression to AIDS or death is probably regulated by the balance of host and viral factors: genetic host susceptibility, immunologic host factors such as qualitative differences in the primary immune response ${ }^{31,32}$ and virologic factors such as extent of HIV-1 replication, viral phenotype, and the immune evasion strategies of HIV-123.

In the HIV/AIDS epidemic, several proven co-factors and additional factors still under study have been related to how fast or slow a person progresses along the pathway towards disease. Socio-demographic characteristics, sexual behaviors, route of infection, and other risk factors associated with the sexual transmission of HIV-1 such as age at first intercourse, number of lifetime partners, and sexually transmitted diseases (STDs) could be some of the determinant host factors for HIV-1 acquisition and progression of the disease $\mathrm{e}^{1,2,7}$. Social features of the communities have been also related to the vulnerability to HIV-1 infection $^{4,26}$.

The HIV-1 epidemic is increasing in Brazil, where over 310,310 cases of HIV/AIDS were notified from 1980 to 2003. The municipality of Londrina ranks second in the number of AIDS cases in the State of Paraná, southern region of Brazil, with a total of 1,070 cases notified between 1984 and $2002^{11}$. The pattern of the HIV/AIDS epidemic in Brazil is heterogeneous and has changed according to time, geographic region, and subpopulations affected ${ }^{15}$. However, few studies have examined host factors associated with the HIV-1 infection in this southern Brazilian population. To address this question, the present cross-sectional study was carried out in order to describe the sociodemographic and epidemiological characteristics associated with the HIV-1 infection, and the seropositivity to other infections that share

(1)Department of Pathology, Clinical Analysis and Toxicology, Health Sciences Center, Londrina State University, Londrina, Paraná, Brazil

(2)Department of Clinical Medicine, Health Sciences Center, Londrina State University, Londrina, Paraná, Brazil

(3)Department of Pathology Sciences, Biological Sciences Center, Londrina State University, Londrina, Paraná, Brazil

(4)Integrated Center of Infectious Diseases of Londrina, Londrina, Paraná, Brazil

(5)Biostatistics, Exact Sciences Center, Londrina State University, Londrina, Paraná, Brazil

(6)School of Medicine, Health Sciences Center, Londrina State University, Londrina, Paraná, Brazil.

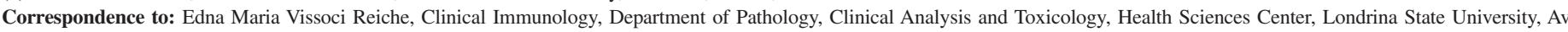

Robert Koch 60, Vila Operária, 86038-440 Londrina, Paraná, Brazil. Phone/FAX number: +55.43.3371-2619. E-mail: reiche@ sercomtel.com.br 


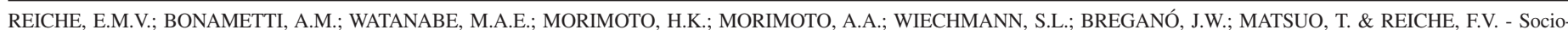
demographic and epidemiological characteristics associated with human immunodeficiency virus type 1 (HIV-1) infection in HIV-1-exposed but uninfected individuals, and in HIV-1infected patients from a southern Brazilian population. Rev. Inst. Med. trop. S. Paulo, 47(5): 239-246, 2005.

the same transmission route with HIV-1, such as syphilis, hepatitis B, hepatitis C, and human T lymphotropic virus type I and II (HTLV I/II) infection in a southern Brazilian cohort of healthy individuals, HIV-1exposed but uninfected individuals, and HIV-1-infected individuals in various stages of infection.

\section{MATERIALS AND METHODS}

Study subjects: The convenience sample consisted of individuals consecutively recruited during the period from September 2001 to December 2003. The healthy individuals were recruited at the Blood Bank of the University Hospital of Londrina, north of Paraná State, southern region of Brazil. The HIV-1-exposed but uninfected and HIV1-infected individuals were enrolled in various specialized, public, and nonprofit centers of STDs such as the University Hospital of State University of Londrina; Outpatient Clinic Hospital of the State University of Londrina; Integrated Center of Infectious Diseases of Londrina, and the State Health Services of various cities from the northern region of Paraná State, Brazil. The protocol was approved by the institutional Research Ethics Committees of Londrina State University, the Health State Secretary of Paraná State and the Brazilian National Program of STDs/AIDS of the Ministry of Health. The individuals were invited to participate and informed in detail about the research, and voluntary written consent was obtained from the subjects enrolled. Socio-demographic and epidemiological data associated with HIV-1 infection, and the stage of the disease were obtained at the time of enrollment from September 2001 to December 2003, using a Brazilian government standardized interview questionnaire. The economic level was based on the Criteria for Economic Classification in Brazil ${ }^{8}$. After the inclusion, blood samples were collected for serological and immunological assays. A total of 1,061 individuals were included and divided into four groups.

Group 1: 136 faithful and screened blood donors of the Blood Bank of the University Hospital of Londrina, who were seronegative for antiHIV-1, anti-HTLV I/II, anti-HCV, hepatitis B surface antigen (HBsAg), antibodies to hepatitis B core antigen (anti-HBcAg), Chagas disease, and syphilis, and who had normal serum alanine aminotransferase levels. The individuals were considered to be at low risk for HIV-1 infection according the risk-screening strategies for determining individual risk for HIV-1 infection ${ }^{16}$ and were used as healthy control to compare with other groups according to socio-demographic, sexual and parenteral exposures. Because they have all been screened and were negative to the serological tests evaluated in this study, they were not used to compare the serological results with other groups.

Group 2: 147 HIV-1-exposed but uninfected individuals, with $\geq 2$ consecutive determinations of anti-HIV-1 antibodies by immunological assays. The individuals were considered to be at high risk for infection due to self-reported sexual behavior, injectable drug use, or both ${ }^{16}$. The individuals reported chronic repeated unprotected sexual exposures to an infected partner, considered highly exposed over time, and/or reported a repeated sharing of needles and syringes with HIV-1 infected patients.

Group 3: 161 HIV-1-infected seroprevalent outpatients, without the symptoms of the disease, and with $\mathrm{CD} 4^{+} \mathrm{T}$ cell counts $\geq 350$ cells/ $\mathrm{mm}^{3}$. At the time of enrollment, 102 subjects were receiving no antiretroviral therapy, and 59 were on antiretroviral therapy. The therapeutic schemes used were in accordance with Brazilian government recommendations ${ }^{12}$.

Group 4: 617 HIV-1-infected seroprevalent outpatients and inpatients with the symptoms of the disease and/or CD4 counts $<350$ cells $/ \mathrm{mm}^{3}$, according to the Brazilian criteria for AIDS definition ${ }^{9}$. At the time of enrollment, 128 subjects were receiving no antiretroviral therapy, and 489 were on antiretroviral therapy. The therapeutic schemes used were in accordance with Brazilian government recommendations ${ }^{12}$.

Serological and immunological assays: Peripheral blood samples without anticoagulant, were collected for the serological tests. The screening and confirmatory serological tests for anti-HIV-1 were performed in serum samples according to standard government procedures ${ }^{10}$. The screening tests used were the enzyme immunosorbent assay (ELISA, Murex ${ }^{\mathrm{TM}}$ HIV-1.2.0, Murex Biotech Limited, Dartford Kent England, UK), and the microparticle enzyme-immunoassay (MEIA, Abbott Axsym ${ }^{\mathrm{TM}}$ System, HIV-1/2 gO, Abbott GmbH, Weisbaden, Delkenheim, Germany). The confirmatory tests used were indirect immunofluorescence (slides from Fiocruz Institute, Rio de Janeiro, Brazil) and Western Blot (Genelabs Diagnostics, Singapore). The serological tests for syphilis used were VDRL (RPR Bras®, Laborclin, Curitiba, Paraná) and ELISA (ICE Syphilis ${ }^{\mathrm{TM}}$ Murex Biotech Limited, UK). The serological markers for $\mathrm{HBsAg}$, anti-HBc, anti$\mathrm{HCV}$ antibodies were determined by MEIA (Abbott Axsym ${ }^{\mathrm{TM}}$ System, Abbott Laboratórios, Brazil). The infection with HTLV I/II was investigated by screening serological tests using two ELISA with different antigens: one consisting of purified viral lysates of HTVL-I and HTLV-II with recombinant antigen p21E of HTLV-I (Vironostika HTLV-I/II, Bio-Meriéux, Brazil), and the other with a synthetic peptide from the envelope protein of HTLV I/II and a recombinant transmembrane protein of HTLV-II (Murex HTLV-I+II, Abbott Laboratórios, Brazil). The results of reactive samples were confirmed by Western Blot and/or the polymerase chain reaction (PCR), as described elsewhere ${ }^{35}$. CD $4^{+} \mathrm{T}$ and $\mathrm{CD} 8^{+} \mathrm{T}$ cell counts were determined in peripheral blood samples collected with EDTA anticoagulant and by flow cytofluorimetry (FACSCount ${ }^{\mathrm{TM}}$ Becton, Dickinson and Company, San Jose, CA, USA). The results were recorded as number of cells $/ \mathrm{mm}^{3}$ and were used as one of the criteria for AIDS definition?.

Statistical analysis: A database consisting of socio-demographic and epidemiological characteristics was set up using the EPI INFO software version $6.04 \mathrm{~d}^{18}$. Median, mean and percentage were used to describe the variables. The chi-square and exact Fisher tests were used to analyze the frequencies of the categorical variables in each group. Kruskal-Wallis and Dunn's Tests ${ }^{21}$ were used to analyze the continuous variables and to compare the study groups. The statistical programs used were EPI INFO ${ }^{18}$ and $\mathrm{SAS}^{44}$. Differences between groups were considered to be statistically significant when $\mathrm{p}<0.05$.

\section{RESULTS}

Socio-demographic and epidemiological characteristics: Of the 161 HIV-1-infected asymptomatic individuals (Group 3), 142 (88.2\%) were from Londrina municipality, and the other 19 (11.8\%) were from many cities in the north of the State of Paraná, Brazil. Of 617 HIV-1infected individuals with AIDS (Group 4), 543 (88.0\%) were from 


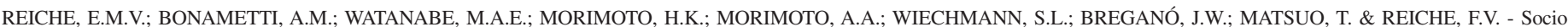
demographic and epidemiological characteristics associated with human immunodeficiency virus type 1 (HIV-1) infection in HIV-1-exposed but uninfected individuals, and in HIV-1infected patients from a southern Brazilian population. Rev. Inst. Med. trop. S. Paulo, 47(5): 239-246, 2005.

Londrina municipality, and the other 74 (12.0\%) were from many cities in the north of the State of Paraná, Brazil.

Table 1 shows the socio-demographic characteristics of the 1,061 subjects according to the four groups. Significant differences were obtained among the four groups when the variables gender, age, marital status, education and economic levels were analyzed. Of them, 570 $(53.7 \%)$ were males and $491(46.3 \%)$ were females. The healthy individuals (Group 1) were predominantly men (57.3\%), and the HIV1 -exposed but uninfected individuals were predominantly women $(59.9 \%)$. The majority $(54.0 \%$ and $56.1 \%)$ of the HIV-infected asymptomatic patients and AIDS cases were men and the male to female ratio were 1.17 and 1.28 , respectively $(\mathrm{p}=0.0046)$. The age of the enrolled subjects ranged from 15.1 to 79.5 years. The healthy individuals were younger than the other subjects, with a median age of 27.2 years, ranging from 18.2-59.8 years. The majority of HIV-1-exposed but uninfected, HIV-1-infected asymptomatic individuals and AIDS cases $(37.9 \%, 37.9 \%$ and $42.5 \%$, respectively) were $30-39$ years old. A total of $2(1.2 \%)$ among the HIV-1 asymptomatic individuals and a total of $15(2.5 \%)$ among the AIDS cases were 60 years old or older $(\mathrm{p}<$ $0.0001)$. The race did not differ among groups $(\mathrm{p}=0.7640)$, since the individuals in groups $1,2,3$, and 4 were predominantly white $(72.1 \%$, $67.3 \%, 65.8 \%$, and $70.5 \%$, respectively). The non-white subjects were Orientals $(n=6,0.6 \%)$, Blacks $(n=67,6.3 \%)$ and Mulattoes $(n=250$, $23.6 \%$ ). The major features of the HIV-1-exposed but uninfected, HIV- 1-infected asymptomatic individuals and AIDS cases were the predominance of married subjects $(76.9 \%, 46.6 \%$ and $43.6 \%$, respectively, $\mathrm{p}<0.0001)$, educational level up to eight years of school $(55.8 \%, 60.2 \%$ and $37.0 \%$, respectively, $\mathrm{p}<0.0001)$ and worst economic conditions $(79.8 \%, 72.7 \%$ and $72.8 \%$, respectively, $\mathrm{p}<$ 0.0001 ), with an income between U\$146 and U\$319. Among the HIV1 -infected asymptomatic individuals and AIDS cases, $14.3 \%$ and $15.2 \%$, respectively, reported an income of up to U\$ 71 .

As regard the route of HIV-1 infection, the results showed significant differences $(\mathrm{p}<0.0068)$, as demonstrated in Table 2 . According to the inclusion criteria, the healthy individuals, considered at low risk for HIV-1 infection, did not report the sexual exposure, and two individuals reported the occurrence of blood transfusion before the HIV/AIDS epidemic. All the 147 HIV-1-exposed but uninfected individuals had been chronically and repeatedly exposed to HIV-1 through unprotected sexual intercourses with HIV-1-infected partners; four of them also had blood exposure through shared needles and syringes with HIV-1-infected individuals, and 13 reported the occurrence of blood transfusion before $(n=5)$ and after $(n=8)$ the HIV/AIDS epidemic. Among the HIV-1-infected asymptomatic patients, $140(87.0 \%)$ self-reported unprotected sexual intercourse with HIV-1-infected individuals, $10(6.2 \%)$ sexual and blood contact through intravenous drugs use (IVDU) or blood transfusion, nine $(5.6 \%)$ reported contact with blood through IVDU $(n=7)$ or blood transfusion

Table 1

Socio-demographic characteristics of healthy individuals, HIV-1 exposed but uninfected individuals, HIV-1 infected asymptomatic patients, and patients with AIDS, from Londrina and region, south of Brazil, October 2001 to December 2003

\begin{tabular}{|c|c|c|c|c|c|}
\hline Characteristic & $\begin{array}{l}\text { Group } 1 \\
\mathrm{n}=136\end{array}$ & $\begin{array}{l}\text { Group } 2 \\
\mathrm{n}=147\end{array}$ & $\begin{array}{l}\text { Group } 3 \\
\mathrm{n}=161\end{array}$ & $\begin{array}{l}\text { Group } 4 \\
n=617\end{array}$ & Total \\
\hline \multicolumn{6}{|l|}{$\overline{\text { Sex }^{a}}$} \\
\hline Male n (\%) & $78(57.3)$ & $59(40.1)$ & $87(54.0)$ & $346(56.1)$ & $570(53.7)$ \\
\hline Rate $\mathrm{M} / \mathrm{F}$ & 1.34 & 0.67 & 1.17 & 1.28 & 1.16 \\
\hline \multicolumn{6}{|l|}{ Age $(\text { years })^{b}$} \\
\hline Range & $18.2-59.8$ & $18.1-73.8^{\S}$ & $14.7-70.4$ & $15.1-79.5^{\S}$ & $15.1-79.5$ \\
\hline Median (Mean) & $27.2(30.0)$ & $36.5(37.3)$ & $32.3(33.7)$ & $36.5(37.4)$ & $35.1-35.9$ \\
\hline \multicolumn{6}{|l|}{ Race $^{c}$} \\
\hline White n $(\%)$ & $98(72.1)$ & $99(67.3)$ & $106(65.8)$ & $435(70.5)$ & 738 (69.6) \\
\hline Non white ${ }^{\S \S} \mathrm{n}(\%)$ & $38(27.9)$ & $48(32.7)$ & $55(34.2)$ & $182(29.5)$ & $323(30.4)$ \\
\hline \multicolumn{6}{|l|}{ Marital status $^{d}$} \\
\hline Never or past married & $73(53.7)$ & $34(23.1)$ & $86(53.8)$ & $348(56.4)$ & $541(51.0)$ \\
\hline Now married & $63(46.3)$ & $113(76.9)$ & $75(46.6)$ & $269(43.6)$ & $520(49.0)$ \\
\hline \multicolumn{6}{|l|}{ Education $^{\mathrm{e}}$} \\
\hline Illiterate & $3(2.2)$ & $5(3.4)$ & $2(1.2)$ & $28(4.5)$ & $38(3.6)$ \\
\hline $1^{\text {st }}-8^{\text {th }}$ grade & $44(32.4)$ & $82(55.8)$ & $97(60.2)$ & $385(62.4)$ & $608(53.7)$ \\
\hline Secondary/Higher & $89(65.4)$ & $60(40.8)$ & $62(38.6)$ & $204(33.1)$ & $415(39.1)$ \\
\hline \multicolumn{6}{|l|}{ Economic level $^{\mathrm{f}}$} \\
\hline $\mathrm{A}$ & $13(9.5)$ & $2(1.4)$ & $2(1.2)$ & $12(1.9)$ & $29(2.73)$ \\
\hline $\mathrm{B}$ & $40(29.4)$ & $21(14.3)$ & $19(11.8)$ & $62(10.1)$ & $142(13.4)$ \\
\hline $\mathrm{C}$ & $46(33.8)$ & $61(41.5)$ & $60(37.3)$ & $192(31.1)$ & 359 (33.8) \\
\hline $\mathrm{D}$ & $37(27.2)$ & $57(38.3)$ & $57(35.4)$ & $257(41.7)$ & $408(38.5)$ \\
\hline $\mathrm{E}$ & $0(0)$ & $6(4.1)$ & $23(14.3)$ & $94(15.2)$ & $123(11.6)$ \\
\hline
\end{tabular}

Group 1: 136 healthy individuals; Group 2: 147 HIV-1 exposed but uninfected individuals; Group 3: 161 HIV-1-infected asymptomatic patients with CD4 T cell counts $\geq 350$ cells $/ \mathrm{mm}^{3}$; Group 4: 617 HIV-1 infected patients with symptoms of the disease and/or CD4 T cell counts $<350$ cells $/ \mathrm{mm}^{3} ;{ }^{\text {a }}$ Chi-square test: $\chi^{2}: 13.0186$, $\mathrm{p}=$ 0.0046; ${ }^{\mathrm{b}}$ Kruskal-Wallis Test: $\mathrm{p}<0.0001 .{ }^{\S}$ The groups did not differ statistically (Dunn Test, $\mathrm{p}=0.4822$ ); ${ }^{\mathrm{c}}$ Chi-square test: $\chi^{2}: 5.76, \mathrm{p}=0.7640 .{ }^{8}{ }^{\S}$ The non-white race individuals included were Orientals $(\mathrm{n}=6)$, Blacks $(\mathrm{n}=67)$, and Mulattoes $(\mathrm{n}=250)$; ${ }^{\mathrm{d}}$ Marital status: never married included single $(\mathrm{n}=380)$; past married included divorced $(\mathrm{n}=81)$, and widowed $(\mathrm{n}=80)$. Chi-square test: $\chi^{2}: 53.66 ; \mathrm{p}<0.0001$; ${ }^{\mathrm{e}}$ : Chi-square test: $\chi^{2}: 52.64 ; \mathrm{p}<0.0001 ;{ }^{\text {f: }}$ Chi-square test: $\chi^{2}: 120.40 ; \mathrm{p}<0.0001$. 


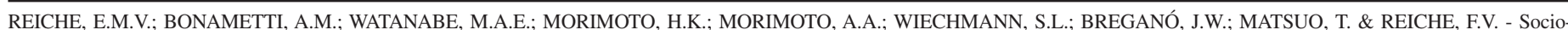
demographic and epidemiological characteristics associated with human immunodeficiency virus type 1 (HIV-1) infection in HIV-1-exposed but uninfected individuals, and in HIV-1infected patients from a southern Brazilian population. Rev. Inst. Med. trop. S. Paulo, 47(5): 239-246, 2005.

Table 2

Risk factors associated with HIV-1 infection in healthy individuals, HIV-1 exposed but uninfected individuals, HIV-1-infected asymptomatic, and patients with AIDS, from Londrina and region, south of Brazil, October 2001 to December 2003.

\begin{tabular}{|c|c|c|c|c|c|}
\hline Risk factors & $\begin{array}{l}\text { Group } 1 \\
\text { No. }(\%)\end{array}$ & $\begin{array}{l}\text { Group } 2 \\
\text { No. (\%) }\end{array}$ & $\begin{array}{l}\text { Group } 3 \\
\text { No. }(\%)\end{array}$ & $\begin{array}{l}\text { Group } 4 \\
\text { No. (\%) }\end{array}$ & $\begin{array}{l}\text { Total } \\
\text { No. }(\%)\end{array}$ \\
\hline \multicolumn{6}{|l|}{ Route of infection a } \\
\hline Sexual & $0(0)$ & $130(88.4)$ & $140(87.0)$ & $506(82.0)$ & $776(83.7)$ \\
\hline Other ${ }^{\S}$ & $2(100.0)$ & 17 (11.6) & $21(13.0)$ & $111(18.0)$ & $151(16.3)$ \\
\hline \multicolumn{6}{|l|}{ IVDU $^{\mathrm{b}}$} \\
\hline Yes & $0(0)$ & $3(2.0)$ & $17(10.6)$ & $85(13.8)$ & $105(9.9)$ \\
\hline No & $136(100.0)$ & $144(98.0)$ & $144(89.4)$ & $532(86.2)$ & $956(90.1)$ \\
\hline \multicolumn{6}{|l|}{ Hemophilia $^{c}$} \\
\hline Yes & $0(0)$ & $0(0)$ & $2(1.2)$ & $5(0.8)$ & $7(0.7)$ \\
\hline No & $136(100.0)$ & 147 (100.0) & $159(98.8)$ & $612(99.2)$ & $1054(99.3)$ \\
\hline \multicolumn{6}{|l|}{ Blood transfusion ${ }^{d}$} \\
\hline Yes & $2(1.5)$ & $13(8.8)$ & $5(3.1)$ & $29(4.7)$ & 49 (4.6) \\
\hline No & $134(98.5)$ & $134(91.2)$ & $156(96.9)$ & $584(95.3)$ & $1008(95.4)$ \\
\hline \multicolumn{6}{|l|}{ Sexual behavior ${ }^{\mathrm{e}}$} \\
\hline Heterosexual & $119(87.5)$ & $135(91.8)$ & $121(75.1)$ & $513(83.1)$ & $888(83.7)$ \\
\hline $\begin{array}{l}\text { Men who have sex } \\
\text { with men }\end{array}$ & $3(2.5)$ & $12(8.2)$ & $40(24.8)$ & $100(16.3)$ & 155 (14.9) \\
\hline
\end{tabular}

Group 1: 136 healthy individuals; Group 2: 147 HIV-1 exposed but uninfected individuals; Group 3: 161 HIV-1-infected asymptomatic patients with CD4 T cell counts $\geq 350$ cells $/ \mathrm{mm}^{3}$; Group 4: 617 HIV-1 infected patients with symptoms of the disease and/or CD4 T cell counts $<350$ cells/mm ${ }^{3}$. $:$ : Group 1: blood transfusion $(\mathrm{n}=2)$; Group 2: sexual and blood exposures $(n=17)$; Group 3: sexual and blood exposures $(n=10)$; blood exposure $(n=9)$; accident with blood ( $n=2)$; Group 4: sexual and blood exposures $(n=36)$; blood exposure $(n=68)$; accident with blood $(n=2)$; tattoo $(n=3)$; mother-to-child transmission $(n=2)$. a: Fisher exact test, $p<0.0001$. b: intravenous drug use (IVDU): Chi-square test, $\chi^{2}: 35.6064, \mathrm{p}<0.0001$; : Fisher exact test, $\mathrm{p}=0.5154$; d: Chi-square test, $\chi^{2}: 9.8345 ; \mathrm{p}=0.0200$; e: 18 individuals without sexual activity were excluded (Group $1, \mathrm{n}=14$; Group $4, \mathrm{n}=4$ ). Chi-square test, $\chi^{2}: 37.1856 ; \mathrm{p}<0.0001$.

$(\mathrm{n}=2)$, and two $(1.2 \%)$ reported an accident with blood. Among the AIDS cases, the sexual route was predominant, reported by $506(82.0 \%)$ of patients; 36 (5.8\%) reported sexual and blood contact through IVDU, blood transfusion or an accident with blood, and $68(11.0 \%)$ had contact with blood through IVDU, blood transfusion or an accident with blood. Other routes of infections reported were work accident $(n=1)$, vertical transmission $(\mathrm{n}=2)$, tattoo $(\mathrm{n}=3)$, and unknown $(\mathrm{n}=1)$. Overall, the IVDU was reported by three $(2.0 \%), 17(10.6 \%)$ and $85(13.8 \%)$ of the HIV-1-exposed but uninfected, HIV-1-infected asymptomatic and AIDS patients, respectively $(\mathrm{p}=0.514)$. A history of blood or hemocomponent transfusion was reported by 13 (8.8\%), five (3.1\%) and $29(4.7 \%)$ of the HIV-1-exposed but uninfected, HIV-1-infected asymptomatic and AIDS patients, respectively $(\mathrm{p}=0.020$ ). As regard the sexual behavior, the age at first sexual experience, and the number of lifetime partners, 14 individuals from Group 1 and four from Group 4 who had not sexual experience were excluded from the statistical analysis of these categories. Among the 1,043 individuals evaluated, the self-reports demonstrated the predominance of heterosexual behaviour in the Groups $1,2,3$, and $4(97.5 \%, 91.8 \%, 75.2 \%$, and $83.7 \%$, respectively). The HIV-1 exposed but uninfected individuals showed the highest rate of heterosexual behavior $(\mathrm{p}<0.0001)$.

The results of other sexual behaviors evaluated such as age at first sexual experience, number of lifetime partners and the occurrence of previous STDs (Table 3), were significantly different for all of these variables $(\mathrm{p}<0.0001)$. Age at first sexual experience before 15 years was reported by $42.9 \%$ and $42.4 \%$ of the individuals from groups 3 and 4, respectively; the HIV-1-infected asymptomatic individuals and patients with AIDS reported the highest number of lifetime partners ( $p$ $<0.0001)$ and more previous STDs $(\mathrm{p}<0.0001)$. Of the STDs mentioned, the patients with AIDS reported the highest rates of gonorrhoea $(20.1 \%, \mathrm{p}<0.0001)$, syphilis $(10.7 \%, \mathrm{p}<0.0001)$, condyloma $(9.4 \%, \mathrm{p}=0.0017)$, and genital herpes $(3.2 \%, \mathrm{p}=0.0293)$ compared to the other groups.

Serological results: Table 4 shows the seropositivity for other infections that share the same route of HIV-1 transmission. The Group 1 was excluded from the statistical analysis to compare the results of the seropositivity with the other groups, because they have all been screened and were negative to the serological tests evaluated in this study.

The patients with AIDS showed the highest rates of reactivity for syphilis, with values of $6.3 \%$ when assessed by VDRL $(p=0.1133)$ and $25.6 \%$ when assessed by ELISA $(p=0.0010)$. For the HBV serological markers evaluated, the HIV-1 infected asymptomatic and AIDS patients showed higher reactivity to HBsAg $(3.3 \%$ and $3.8 \%$, respectively) and to anti-HBc (36.5\% and $37.4 \%$, respectively) than the HIV-1 exposed but uninfected individuals. However, the difference of reactivity was not significant. As regards anti-HCV antibodies, the difference was significant. HIV-1-infected patients showed higher rates, with $16.0 \%$ of reactivity among the asymptomatic cases and $22.3 \%$ among the AIDS cases than the HIV-1 exposed but uninfected individuals $(\mathrm{p}<0.0001)$.

Table 5 shows the positivity for HTLV I/II infection. The rates of seropositivity were higher among the HIV-1 infected asymptomatic and AIDS patients than HIV-1 exposed but uninfected individuals when the screening serological tests of ELISA were considered $(p=0.0368$ for ELISA with lysate and recombinant antigens, and $p=0.0066$ for 


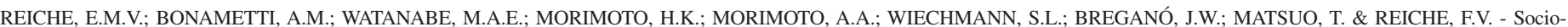

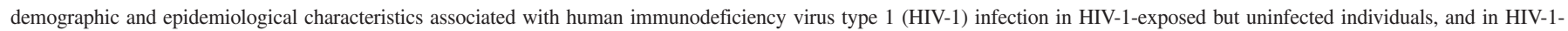
infected patients from a southern Brazilian population. Rev. Inst. Med. trop. S. Paulo, 47(5): 239-246, 2005.

Table 3

Risk factors associated with sexual transmission of HIV-1 infection in healthy individuals, HIV-1 exposed but uninfected individuals, HIV-1-infected asymptomatic, and patients with AIDS, from Londrina and region, south of Brazil, October 2001 to December 2003

\begin{tabular}{|c|c|c|c|c|c|}
\hline Risk factors & $\begin{array}{l}\text { Group } 1 \\
\text { No. }(\%)\end{array}$ & $\begin{array}{l}\text { Group } 2 \\
\text { No. (\%) }\end{array}$ & $\begin{array}{l}\text { Group } 3 \\
\text { No. }(\%)\end{array}$ & $\begin{array}{l}\text { Group } 4 \\
\text { No. (\%) }\end{array}$ & $\begin{array}{l}\text { Total } \\
\text { No. }(\%)\end{array}$ \\
\hline \multicolumn{6}{|l|}{ Age at first sex } \\
\hline after age 15 & $26(21.3)$ & $47(32.0)$ & $69(42.9)$ & $260(42.1)$ & $402(37.9)$ \\
\hline before age 15 & $96(78.7)$ & $100(68.0)$ & $92(57.1)$ & $353(57.2)$ & $641(61.5)$ \\
\hline \multicolumn{6}{|c|}{ Number of lifetime partners ${ }^{b}$} \\
\hline 1 & $41(33.6)$ & 45 (30.6) & $19(11.9)$ & $38(6.3)$ & 143 (13.8) \\
\hline $2-10$ & $58(47.5)$ & $64(43.5)$ & $74(46.6)$ & $302(49.6)$ & $498(48.1)$ \\
\hline$>10$ & $23(18.9)$ & $38(25.9)$ & $66(41.5)$ & $268(44.1)$ & $395(38.1)$ \\
\hline \multicolumn{6}{|l|}{ Previous DST ${ }^{c}$} \\
\hline Yes & $4(3.0)$ & $30(20.4)$ & $52(32.5)$ & $233(38.1)$ & $319(30.2)$ \\
\hline No & $132(97.0)$ & $117(79.6)$ & $108(67.5)$ & $379(61.9)$ & $736(69.8)$ \\
\hline \multicolumn{6}{|l|}{ Previous DST } \\
\hline Gonorrhoea $^{\mathrm{d}}$ & $3(2.2)$ & $15(10.20)$ & $27(16.8)$ & $124(20.1)$ & $169(15.9)$ \\
\hline Syphilis ${ }^{\mathrm{e}}$ & $1(0.7)$ & $3(2.0)$ & $13(8.1)$ & $66(10.7)$ & $83(7.8)$ \\
\hline Genital Herpes ${ }^{f}$ & $0(0)$ & $5(3.4)$ & $1(0.6)$ & $20(3.2)$ & $26(2.4)$ \\
\hline Condyloma ${ }^{\mathrm{g}}$ & $1(0.7)$ & $7(4.8)$ & $9(5.6)$ & $58(9.4)$ & $75(7.1)$ \\
\hline
\end{tabular}

Group 1: 136 healthy individuals; Group 2: 147 HIV-1 exposed but uninfected individuals; Group 3: 161 HIV-1-infected asymptomatic patients with CD4 T cell counts $\geq 350$ cells $/ \mathrm{mm}^{3}$; Group 4: 617 HIV-1 infected patients with symptoms of the disease and/or CD4 T cell counts $<350$ cells $/ \mathrm{mm}^{3}$; a: 18 individuals without sexual activity were excluded (Group 1, $\mathrm{n}=14$; Group 4, $\mathrm{n}=4$ ). Chi-square test, $\chi^{2}: 23.56 ; \mathrm{p}<0.0001 ;{ }^{\text {b: }} 18$ individuals without sexual activity were excluded (Group 1, $\mathrm{n}=14$; Group $4, \mathrm{n}=4)$. Chi-square test, $\chi^{2}: 23.56 ; \mathrm{p}<0.0001$; : Chi-square test, $\chi^{2}: 72.97, \mathrm{p}<0.0001$; d: Chi-square test, $\chi^{2}: 30.81, \mathrm{p}<0.0001$; e: Chi-square test, $\chi^{2}: 23.37$, p < 0.0001; f: Fisher Exact Test, $\mathrm{p}=0.0293$; g: Chi-square test, $\chi^{2}: 15.13, \mathrm{p}=0.0017$.

Table 4

Seropositivity to syphilis, hepatitis B virus and hepatitis C virus infections in healthy individuals, HIV-1 exposed but uninfected individuals, HIV-1 infected asymptomatic, and patients with AIDS, from Londrina and region, south of Brazil, October 2001 to December 2003

\begin{tabular}{|c|c|c|c|c|c|}
\hline Serological result & $\begin{array}{l}\text { Group 1* } \\
\text { No. }(\%)\end{array}$ & $\begin{array}{l}\text { Group } 2 \\
\text { No. (\%) }\end{array}$ & $\begin{array}{l}\text { Group } 3 \\
\text { No. (\%) }\end{array}$ & $\begin{array}{l}\text { Group } 4 \\
\text { No. (\%) }\end{array}$ & $\begin{array}{l}\text { Total } \\
\text { No. }(\%)\end{array}$ \\
\hline \multicolumn{6}{|l|}{ VDRL $^{a}$} \\
\hline Positive & $0(0)$ & $6(4.1)$ & $4(2.5)$ & $39(6.3)$ & 49 (4.6) \\
\hline Negative & $136(100)$ & $141(95.9)$ & $152(94.4)$ & $561(90.9)$ & $990(93.3)$ \\
\hline \multicolumn{6}{|l|}{ ELISA Tp IgG } \\
\hline Positive & $1(0.7)$ & $18(12.2)$ & 30 (18.6) & 158 (25.6) & 207 (19.5) \\
\hline Negative & $135(99.3)$ & $124(84.3)$ & $126(78.3)$ & $451(73.1)$ & $836(78.8)$ \\
\hline \multicolumn{6}{|l|}{ HBsAg $^{c}$} \\
\hline Positive & $0(0)$ & $2(1.4)$ & $6(3.8)$ & $20(3.3)$ & $28(2.7)$ \\
\hline Negative & $136(100)$ & $145(98.6)$ & $150(96.2)$ & $581(96.7)$ & $1012(97.3)$ \\
\hline \multicolumn{6}{|l|}{ Anti-HBc $c^{d}$} \\
\hline Positive & $0(0)$ & $40(27.2)$ & $57(36.5)$ & $225(37.4)$ & $322(31.0)$ \\
\hline Negative & $136(100)$ & $107(72.8)$ & $99(63.5)$ & $376(62.6)$ & $718(69.0)$ \\
\hline \multicolumn{6}{|l|}{ Anti-HCVe } \\
\hline Positive & $0(0)$ & $6(4.1)$ & $25(16.0)$ & $134(22.3)$ & $165(15.9)$ \\
\hline Negative & $136(100)$ & $141(95.9)$ & $131(84.0)$ & 467 (77.7) & $875(84.1)$ \\
\hline
\end{tabular}

Group 1: 136 healthy individuals; Group 2: 147 HIV-1 exposed but uninfected individuals; Group 3: 161 HIV-1-infected asymptomatic patients and CD4 T cells $\geq 350$ cells $/ \mathrm{mm}^{3}$; Group 4: $617 \mathrm{HIV}-1$ infected patients with symptoms of the disease and/or CD4 T cells $<350 \mathrm{cells} / \mathrm{mm}^{3}$. * The Group 1 was excluded for the statistical analysis to compare the seropositivity obtained on the tests. a: Venereal Disease Research Laboratories. Chi-square test. $\chi^{2} 4.36$. degree of freedom: 2 . $p=0.1133$. ${ }^{b}$ : Enzyme-linked immunosorbent assay for specific IgG for Treponema pallidum. Chi-square test $\chi^{2}: 12.85$. degree of freedom: $2, p=0.0010 . c$ : Hepatitis B surface antigen. Exact Fisher test. $\mathrm{p}=0.4088$; d: Antibody against the core antigen of hepatitis B virus. Chi square test $\chi^{2}: 5.46$, degree of freedom: 2 , $p=0.0653$. e: Antibody to hepatitis $\mathrm{C}$ virus. Chi-square test $\chi^{2}: 26.89$, degree of freedom: $2, \mathrm{p}<0.0001$.

ELISA with viral synthetic peptides and recombinant antigens). When the results were evaluated by the confirmatory results, the patients with AIDS showed the highest rates of HTLV I/II infection (6.3\%), followed by HIV-1-infected asymptomatic (2.5\%) and HIV-1-exposed but uninfected $(0.7 \%)$ individuals. However, the difference was not significant among the groups 2,3 , and 4 when the confirmatory tests were considered $(\mathrm{p}=0.2529)$. 


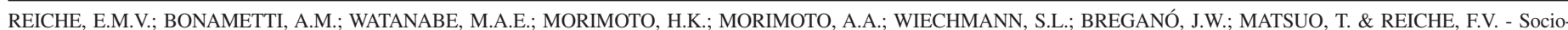
demographic and epidemiological characteristics associated with human immunodeficiency virus type 1 (HIV-1) infection in HIV-1-exposed but uninfected individuals, and in HIV-1infected patients from a southern Brazilian population. Rev. Inst. Med. trop. S. Paulo, 47(5): 239-246, 2005.

\section{DISCUSSION}

Brazil is one of the countries with the greatest number of AIDS cases in the world. Lately, small counties are experiencing relatively high incidence rates when compared to large urban centers. The results obtained in this study confirm the data reported by the Brazilian Ministry of Health and other researches showing the spread of the epidemic from the major urban centers to smaller municipalities across most of Paraná State, southern Brazil, the predominance of the sexual route of transmission, with mainly heterosexual unprotected intercourse, the increased number of HIV/AIDS in women, the increased number of HIV/AIDS among both younger and older individuals, and the predominance of individuals with incomplete basic schooling ${ }^{11,26}$. Although all the main modes of transmission coexist in the southern Brazilian region assessed, with significant levels of risky behavior such as early sexual activity, unprotected sex with multiple partners and the use of contaminated drug-injection equipment, the HIV-1 transmission patterns are changing in the region assessed in this study. The results showed the lower rates of transmission through blood and blood products and of HIV-1 infection associated with injectable drug use at this time in this region. Some factors could explain these results, such as the intrinsic transfusional system and its improvement revealed by the quality of the hemotherapy services carried out in our country and by the prevention programs, including efforts to extend coverage for harm reduction projects. The Ministry of Health, as part of the federal government, politically supports all of these projects and financially supports the majority as well ${ }^{34}$.

The results showing the predominance of HIV-1-infected asymptomatic patients and AIDS cases among the individuals with low educational levels and worst economic conditions compared with the HIV-1-uninfected individuals confirmed previous studies emphasizing the connection between vulnerability to HIV-1 infection and social inequalities ${ }^{4,7,19,26}$. The high prevalence of HIV-1 infection among individuals who only attended primary school or who failed to complete secondary school confirms that the education is a key defense against the spread of HIV.
Taken together, these data confirmed the major features of the HIV/ AIDS epidemic in Brazil, i.e., the steady decrease in the male to female ratio as a result of an increasing proportion of female patients, fueled by heterosexual transmission, and the fact that patients are from the poorer part of society and live farther away from urban centers.

The predominance of patients with AIDS among the HIV-1-infected patients enrolled in this study may reflect the delay in HIV-1 diagnosis and in the access to specialized STDs centers for this population. It may also indicate that this is a population with more time of exposure to the risk factor associated with HIV-1 acquisition.

The self-reports of lower previous STDs and lower lifetime number of sex partners among the faithful blood donors are in agreement with the idea that repeat and altruistic blood donors are safer then replacement donors, and have a lower risk of infectious diseases. This result justifies the concerted efforts in the past years to change the blood donor supply from "replacement" first-time donors to repeat "altruistic" donors in Brazil.

The self-reports of more previous STDs infections, higher lifetime number of sex partners, earlier first sexual experience in the HIV-1infected asymptomatic individuals and in patients with AIDS compared to the healthy individuals and HIV-1 exposed but uninfected individuals confirmed previous studies from different parts of the world which found that high-risk sexual behaviour and STDs play a role in enhancing the transmission of HIV-1 by increasing the susceptibility of non-HIV1 -infected individuals and the infectiousness of HIV-1-infected individuals ${ }^{1,2,13,14}$. Although HIV-1 transmission across intact mucosal surfaces can occur, surface abrasions and breaks in the integrity of the mucosal epithelium increase the risk of HIV-1 infection. STDs and other factors amplifying inflammatory $\mathrm{T}$ cell populations in regional mucosal sites also exacerbate HIV-1 transmission ${ }^{45}$. The higher seropositivity to the treponemal test for syphilis, to $\mathrm{HBV}, \mathrm{HCV}$ and HTLV I/II infections in patients with AIDS compared to the HIV-1 exposed but uninfected individuals confirmed the strong association

Table 5

Results of the human T lymphocyte virus type I and I (HTLV I/II) infection, obtained by the serological screening and confirmatory tests, in healthy individuals. HIV-1 exposed but uninfected individuals, HIV-1-infected asymptomatic, and patients with AIDS, from Londrina and region, south of Brazil, October 2001 to December 2003

\begin{tabular}{|c|c|c|c|c|c|}
\hline Result & $\begin{array}{l}\text { Group } 1 * \\
\text { No. }(\%)\end{array}$ & $\begin{array}{l}\text { Group } 2 \\
\text { No. }(\%)\end{array}$ & $\begin{array}{l}\text { Group } 3 \\
\text { No. }(\%)\end{array}$ & $\begin{array}{l}\text { Group } 4 \\
\text { No. }(\%)\end{array}$ & $\begin{array}{l}\text { Total } \\
\text { No. }(\%)\end{array}$ \\
\hline \multicolumn{6}{|c|}{ Anti-HTLV I/II a } \\
\hline Positive & $0(0)$ & $2(1.4)$ & $6(3.7)$ & $38(6.2)$ & $46(4.3)$ \\
\hline Negative & $136(100)$ & 145 (98.6) & $150(93.2)$ & $564(91.4)$ & $995(93.8)$ \\
\hline \multicolumn{6}{|c|}{ Anti-HTLV I/II b } \\
\hline Positive & $0(0)$ & $1(0.7)$ & $6(3.7)$ & $42(6.8)$ & 49 (4.6) \\
\hline Negative & $136(100)$ & $146(99.3)$ & $150(93.2)$ & $560(90.8)$ & $992(93.5)$ \\
\hline \multicolumn{6}{|c|}{ WB and/or PCR ${ }^{c}$} \\
\hline Positive & $0(0)$ & $1(0.7)$ & $4(2.5)$ & $39(6.3)$ & $44(4.1)$ \\
\hline Negative & $0(0)$ & $0(0)$ & $2(1.2)$ & $4(0.6)$ & $6(0.6)$ \\
\hline
\end{tabular}

Group 1: 136 healthy individuals; Group 2: 147 HIV-1-exposed but uninfected individuals; Group 3:161 HIV-1-infected asymptomatic patients with CD4 T cell counts $\geq 350$ cells $/ \mathrm{mm}^{3}$; Group 4: $617 \mathrm{HIV}-1$ infected patients with symptoms of the disease and/or CD4 T cell counts $<350$ cells/mm ${ }^{3}$. The Group 1 was excluded for the statistical analysis to compare the seropositivity obtained on the tests. a: Enzyme-linked immunosorbent assay with viral lysates and recombinant antigens. Chi-square test $\chi^{2}: 6.60$, degree of freedom: $2 \mathrm{p}=0.0368$. b: Enzyme-linked immunosorbent assay with viral synthetic peptides and recombinant antigens Chi-square test $\chi^{2}: 10.05$, degree of freedom: 2, $\mathrm{p}=0.0066$. c: Western Blot and/or Polymerase Chain Reaction. Exact Fisher test, $\mathrm{p}=0.2529$. 


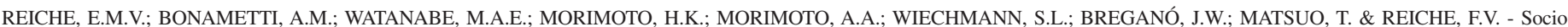
demographic and epidemiological characteristics associated with human immunodeficiency virus type 1 (HIV-1) infection in HIV-1-exposed but uninfected individuals, and in HIV-1infected patients from a southern Brazilian population. Rev. Inst. Med. trop. S. Paulo, 47(5): 239-246, 2005.

between past/current syphilis and HIV-1 infection emphasizing the important role played by syphilis in the spread of HIV-1 infection, most likely as a co-factor of HIV-1 transmission, had already been identified in previous studies ${ }^{1,2,46}$. The presence of concomitant STDs at the time of HIV-1 inoculation is associated with increased risk for infection and increased progression, which may be due to inflammation, ulceration, and breakdown in local barriers but also to nonspecific systemic inflammation and release of cytokines that produce systemic immune activation ${ }^{25,37,40,43,46}$. Alternatively, greater sexual activity could increase the hazard of exposure to a more virulent HIV-1 strain ${ }^{37}$.

As regards syphilis, the infection with Treponema pallidum was assessed by a nontreponemal serological test (VDRL) and a treponemal serological test (ELISA) and therefore individuals with positive syphilis serology included recently infected individuals, as well as men and women with old and/or untreated infections. This may explain the increase observed in the rates of syphilis seropositivity when assessed by ELISA in all groups.

The rates of seropositivity obtained for other infections that share the same route of the HIV-1 transmission may reflect the life style of the population assessed. The highest levels of seropositivity for syphilis, HBV, HCV and HTLV I/II infections in the HIV-1-infected patients was expected and confirmed the overlapping of the routes of transmission of these microorganisms. The high seropositivity to these serological markers in HIV-1 patients was also reported in previous studies carried out on Brazil ${ }^{22,33,41}$. In addition, co-infections such as HCV infection ${ }^{20,29,38}$ and HTLV I/II infection ${ }^{3,6,28}$ have been reported to be risk factors for HIV-1 infection and disease progression.

The pathogenic mechanisms of HIV-1 infection are multifactorial and the effect of a given factor on the risk to acquire and/or to delay the disease progression will be relative. However, the results obtained in the present study may be useful in documenting the predominant socio-demographic and epidemiological characteristics for HIV-1 infection among the residents of Londrina and region of Paraná State, located in southern Brazil. We hope that these data will contribute to the improvement of the current HIV-1 prevention, monitoring and therapeutic programs targeted at this population.

\section{RESUMO}

\section{Características sociodemográficas e epidemiológicas associadas com a infecção pelo vírus da imunodeficiência humana tipo 1 (HIV-1) em indivíduos expostos ao HIV-1 mas não infectados e em pacientes infectados pelo $\mathrm{HIV}-1$, provenientes da população da região Sul do Brasil}

Este estudo transversal descreve as principais características sociodemográficas e epidemiológicas associadas com a infecção pelo HIV-1 em 1.061 indivíduos atendidos em Londrina e região, Sul do Brasil: 136 indivíduos saudáveis (Grupo 1), 147 indivíduos expostos ao HIV-1 mas não infectados (Grupo 2), 161 pacientes infectados pelo HIV-1 assintomáticos (Grupo 3) e 617 pacientes com aids (Grupo 4). Os dados foram obtidos pela aplicação de um questionário padronizado e realização de testes sorológicos. A idade dos indivíduos variou de 15,1 a 79,5 anos; $54,0 \%$ e $56,1 \%$ dos pacientes dos Grupos 3 e 4, respectivamente, eram homens. As principais características dos indivíduos dos Grupos 2, 3 e 4 foram o predomínio do nível educacional com até oito anos de escolaridade $(58,8 \%, 60,2 \%$ e $62,4 \%$, respectivamente), a via sexual de transmissão $(88,4 \%, 87,0 \%$ e $82,0 \%$, respectivamente), o comportamento heterossexual $(91,8 \%, 75,2 \%$ e $83,7 \%$, respectivamente) e antecedentes de doenças sexualmente transmissíveis $(20,4 \%, 32,5 \%$ e $38,1 \%$, respectivamente). Os pacientes com aids apresentaram os valores mais elevados de soropositividade para sífilis $(25,6 \%)$, anti-HCV $(22,3 \%)$ e anti-HTLV I/II em dois testes de triagem sorológica $(6,2 \%$ e $6,8 \%$, respectivamente). Os resultados documentando as características predominantes associadas com a infecção pelo HIV-1 observada nos indivíduos de Londrina e região, poderá ser útil na melhoria dos atuais programas de prevenção, monitoramento e de tratamento da infecção pelo HIV-1 dirigidos a esta população.

\section{ACKNOWLEDGMENTS}

We thank the Health Ministry - Brazilian National Sexual Transmitted Disease/AIDS Program (CN-DST/AIDS), for their financial support with the cooperative agreement of the State University of Londrina (Grants UNESCO-UEL CFA 667/01), the Londrina University Hospital for technical and administrative support, and the PIBIC CNPq Program for the student grant.

\section{REFERENCES}

1. AKLILU, M.; MESSELE, T.; TSEGAYE, A. et al. - Factors associated with HIV-1 infection among sex workers of Addis Ababa, Ethiopia. AIDS, 15: 87-96, 2001.

2. ALARCON, J.O.; JOHNSON, K.M.; COURTOIS, B. et al. - Determinants and prevalence of HIV infection in pregnant Peruvian women. AIDS, 17: 613-618, 2003.

3. ARAI, M.; OHASHI, T.; TSUKAHARA, T. et al. - Human T-cell leukemia virus type 1 Tax protein induces the expression of lymphocyte chemoattractant SDF-1/PBSF. Virology, 241: 298-303, 1998.

4. BARBOSA, L.M. - Profiles of social vulnerability to the infection by HIV of the populations of Northeast Brazilians. In: SIMPÓSIO BRASILEIRO DE PESQUISA EM HIV/AIDS, 5., Rio de Janeiro. 2003. Resumos. p. 33.

5. BARCELLINI, W.; RIZZARDI, G.P.; VELATI, C. et al. - In vitro production of type 1 and type 2 cytokines by peripheral blood mononuclear cells from high-risk HIVnegative intravenous drug users. AIDS, 9: 691-694, 1995.

6. BARTHOMOLEW, C.; BLATTNER, W. \& CLEGHORN, F. - Progression to AIDS in homosexual men co-infected with HIV and HTLV-I in Trinidad. Lancet, 2: 1469, 1987.

7. BATES, I.; FENTON, C.; GRUBER, J. et al. - Vulnerability to malaria, tuberculosis, and HIV/AIDS infection and disease. Part 1: determinants operating at individual and household level. Lancet, 4: 267-277, 2004.

8. BRASIL. ASSOCIAÇÃO NACIONAL DE EMPRESAS DE PESQUISA (ANEP) Critérios de classificação econômica Brasil. URL: http://www.anep.org.br. Captured in $05 / 11 / 2000$.

9. BRASIL. Ministério da Saúde. Secretaria de Políticas de Saúde. Coordenação Nacional de DST e AIDS - Revisão da definição nacional de caso de AIDS em indivíduos com 13 anos ou mais, para fins de vigilância epidemiológica. Brasília, Ministério da Saúde, 1998.

10. BRASIL. Ministério da Saúde. Agência Nacional de Vigilância Sanitária - Portaria no 488 de 17 de junho de 1998. 


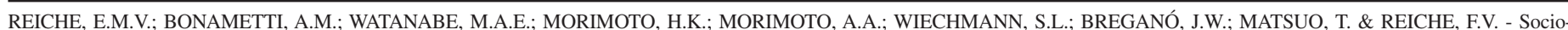
demographic and epidemiological characteristics associated with human immunodeficiency virus type 1 (HIV-1) infection in HIV-1-exposed but uninfected individuals, and in HIV-1infected patients from a southern Brazilian population. Rev. Inst. Med. trop. S. Paulo, 47(5): 239-246, 2005.

11. BRASIL. Ministério da Saúde. Coordenação de DST e AIDS - 01 à 52 semanas epidemiológicas janeiro a dezembro de 2003. Bol. Epidem.AIDS, 17(1), 2003.

12. BRASIL. Ministério da Saúde - Recomendações para terapia anti-retroviral em adultos e adolescentes infectados pelo HIV 2002/2003. Brasília, 2002. URL: http:/ /www.aidsw.gov.br. Captured in 27/12/2002.

13. BUVÉ, A.; WEISS, H.A.; LAGA, M. et al. - The epidemiology of trichomoniasis in women in four African cities. AIDS, 5 (suppl. 4): S89-S96, 2001.

14. BUVÉ, A.; WEISS, H.A.; LAGA, M. et al. - The epidemiology of gonorrhoea, chlamydial infection and syphilis in four African cities. AIDS, 15 (suppl. 4 ): S79-S88, 2001.

15. CAIAFFA, W.T.; PROIETTI, F.A.; CARNEIRO-PROIETTI, A.B. et al. - The dynamics of the human immunodeficiency virus epidemics in the south of Brazil: increasing role of injection drug users. Clin. infect. Dis., 37 (suppl. 5): S376-S381, 2003.

16. CENTERS FOR DISEASE CONTROL AND PREVENTION - Revised guidelines for HIV counseling, testing, and referral and revised recommendations for HIV screening of pregnant women. M.M.W.R., 50 (RR-19): 8-9, 2001.

17. CLERICI, M.; GIORGI, J.V.; CHOU, C.C. et al. - Cell-mediated immune response to human immunodeficiency virus (HIV) type 1 in seronegative homosexual men with recent sexual exposure to HIV-1. J. infect. Dis., 165: 1012-1019, 1992.

18. DEAN, A.G.; DEAN, J.Á.; COULOMBIER, D. et al. - World-processing database, and statistics program for public health on IBM-compatible microcomputers. Atlanta, Centers for Disease Control and Prevention, 1995.

19. DHALIA, C.; BARREIRA, D. \& CASTILHO, E.A. - A aids no Brasil. Situação atual e tendências. Bol. Epidem. AIDS, 17 (1): 3-13, 2000.

20. DORRUCCI, M.; PEZZOTTI, P.; PHILLIPS, A.N.; LEPRI, A.C. \& REZZA, G. - Coinfection of hepatitis $\mathrm{C}$ virus with human immunodeficiency virus and progression to AIDS. Italian Seroconversion Study. J. infect. Dis., 172: 1503-1508, 1995.

21. DUNN, O.J. - Multiple comparisons using rank sums. Technometrics, 6: 241-252, 1964.

22. ETZEL, A.; SHIBATA, G.Y.; ROZMAN, M. et al. - HTLV-1 and HTLV-2 infections in HIV-infected individuals from Santos, Brazil: seroprevalence and risk factors. J. AIDS hum. Retrov., 26: 185-190, 2001.

23. EVANS, D.T. \& DESROSIERS, R.C. - Immune evasion strategies of the primate lentiviruses. Immunol. Rev., 183: 141-158, 2001.

24. FAUCI, A.S.; PANTALEO, G.; STANLEY, S. \& WEISSMAN, D. - Immunopathogenic mechanisms of HIV infection. Ann. intern. Med., 124: 654-663, 1996.

25. FLEMING, D.T. \& WASSERHEIT, J.N. - From epidemiological synergy to public health policy and practice: the contribution of other sexually transmitted diseases to sexual transmission of HIV infection. Sex. transm. Infect., 75: 3-17, 1999.

26. FONSECA, M.G.; SZWARCWALD, C.L. \& BASTOS, F.I. - Análise sociodemográfica da epidemia de aids no Brasil, 1989-1997. Rev. Saúde públ. (S. Paulo), 36: 678$685,2002$.

27. FOWKE, K.R.; NAGELKERKE, N.J.; KIMANI, J. et al. - Resistance to HIV-1 infection among persistently seronegative prostitutes in Nairobi, Kenya. Lancet, 348: 1347$1351,1996$.

28. GREENE, W.C.; BOHNLEIN, E. \& BALLARD, D.W. - HIV-1, HTLV-I and normal Tcell growth: transcriptional strategies and surprises. Immunol. today, 10: 272-278, 1989.

29. GREUB, G.; LEDERGERBER, B.; BATTEGAY, M. et al. - Clinical progression, survival, and immune recovery during antiretroviral therapy in patients with HIV-1 and hepatitis C virus coinfection: the Swiss HIV Cohort Study. Lancet, 356: 1800-1805, 2000 .
30. HOGAN, C. \& HAMMER, S.M. - Host determinants in HIV infection and disease. Part 1. Cellular and humoral immune responses. Ann. intern. Med., 134: 761-776, 2001.

31. HOGAN, C. \& HAMMER, S.M. - Host determinants in HIV infection and disease. Part 2. Genetic factors and implications for antiretroviral therapeutics. Ann. intern. Med., 134: 978-996, 2001.

32. LIFSON, A.R.; BUCHBINDER, S.P.; SHEPPARD, H.W. et al. - Long-term human immunodeficiency virus infection in asymptomatic homosexual and bisexual men with normal CD4+ lymphocyte counts: immunologic and virologic characteristics. J. infect. Dis., 163: 959-965, 1991.

33. MENDES-CORRÊA, M.C.; BARONE, A.A. \& GUASTINI, C. - Hepatitis C virus seroprevalence and risk factors among patients with HIV infection. Rev. Inst. Med. trop. S. Paulo, 43: 15-19, 2001.

34. MESQUITA, F.; DONEDA, D.; GANDOLFI, D. et al. - Brazilian response to the human immunodeficiency virus/acquired immunodeficiency syndrome epidemic among infection drug users. Clin. infec. Dis., 37 (suppl. 5): S383-S385, 2003.

35. MORIMOTO, H.K. - Infecção pelos vírus linfotrópicos de células T humanas dos tipos I (HTLV I) e II (HTLV II) em indivíduos infectados pelo vírus da imunodeficiência humana (HIV) em Londrina e região, Paraná. São Paulo, 2003. (Dissertação de Mestrado - Faculdade de Ciências Farmacêuticas da Universidade de São Paulo).

36. PANTALEO, G.; GRAZIOSI, C.; DEMAREST, J.F. et al . - HIV infection is active and progressive in lymphoid tissue during the clinically latent stage of disease. Nature, 362: $355-358,1993$

37. PHAIR, J.; JACOBSON, L.; DETELS, R. et al. - Acquired immune deficiency syndrome occurring within 5 years of infection with human immunodeficiency virus type-1: the Multicenter AIDS Cohort Study. J. Acquir. Immune Defic. Syndr., 5: 490-496, 1992.

38. PIROTH, L.; GRAPPIN, M.; CUZIN, L. et al. - Hepatitis C virus co-infection is a negative prognostic factor for clinical evolution in human immunodeficiency virus-positive patients. J. viral Hepatitis, 7: 302-308, 2000.

39. PLUMMER, F.A.; BALL, T.B.; KIMANI, J. \& FOWKE, K.R. - Resistance to HIV-1 infection among highly exposed sex workers in Nairobi: what mediates protection and why does it develop? Immunol. Lett., 66: 27-34, 1999.

40. PLUMMER, F.A. - Heterosexual transmission of human immunodeficiency virus type (HIV-1): interactions of conventional sexually transmitted diseases, hormonal contraception and HIV-1. AIDS Res. Hum. Retroviruses, 14 (suppl. 1): S5-S10, 1998.

41. REICHE, E.M.; VOGLER, I.H.; MORIMOTO, H.K. et al. - Evaluation of surrogate markers for human immunodeficiency virus infection among blood donors at the blood bank of Hospital Universitário Regional Norte do Paraná, Londrina, PR, Brazil. Rev. Inst. Med. trop. S. Paulo, 45: 23-27, 2003.

42. ROSENBERG, Z.F. \& FAUCI, A.S. - Immunopathogenesis of HIV infection. FASEB J., 5: 2382-2390, 1991.

43. ROYCE, R.A.; SENA, A.; CATES Jr., W. \& COHEN, M.S. - Sexual transmission of HIV. New Engl. J. Med., 336: 1072-1078, 1997.

44. SAS - SAS/STAT user's guide, Version 6. 4. ed., Cary, SAS Institute, 1989.

45. WAHL, S.M.; SMITH, P.D. \& JANOFF, E.N. - Human immunodeficiency virus type 1 infection, mucosal immunity, and pathogenesis: comments and conference summary. J. infect. Dis., 179 (suppl. 3): S397-S400, 1999.

46. WASSERHEIT, J.N. - Epidemiological synergy: interrelationships between human immunodeficiency virus infection and other sexually transmitted diseases. Sex. transm. Dis., 19: 61-77, 1992.

Received: 27 April 2005

Accepted: 27 July 2005 